\title{
BIRD SIGHTINGS IN NORTHERN SASKATCHEWAN, AUGUST 1986
}

\section{F. J. HARTLEY FREDEEN, 410 Leslie Avenue, Saskatoon SK S7H $2 Z 1$}

On reading the interesting reports by Nero and Renaud, I realized I might be able to add a few useful observations about 26 species of birds in northeastern Saskatchewan. ${ }^{1,2}$

On August 10 to 29 inclusive, 1986, my brother Howard, his son Greg, and I canoed down Wollaston Lake, the Fond du Lac River and the eastern arm of Lake Athabasca. We camped for two nights on the west bank of the MacFarlane River on the south side of Lake Athabasca before crossing the lake to Black Bay to meet a DeHaviland Beaver for the return trip to Wollaston Lake with our canoe.

Our trip was, unfortunately, limited in time, and much of that time was spent navigating rapids and lakes (Wollaston, Hatchet, Black and Athabasca, to name the largest). We used a 4 HP sidemounted outboard motor on these lakes. We experienced rain and sometimes high winds almost every day, so camp preparations were more elaborate than expected. Westerly winds on August 23 to 25 were severe enough to sink a string of supply barges on Lake Athabasca and raise the water level at Stony Rapids about $5 \mathrm{~m}$, causing havoc with wharves, boats and pontoon planes. The dates and locations of our encampments are listed in Table 1 and were used as reference points for our observations. Thus, where dates but not locations are cited in the text, refer to appropriate dates in Table 1. For example, we camped at the southwest end of Wollaston Lake on the night of August 10-11, and camped at the northwest corner on the night of August
11-12. Thus, August 11 was spent travelling between these two camps of which the coordinates are listed in Table 1.

COMMON LOON - Loons were heard calling at several locations near the northwest corner of Wollaston Lake on August 11.

TUNDRA SWAN - On August 19, a flock of 16 flew over our campsite near the middle of the south side of Black Lake.

CANADA GOOSE - On August 16, a flock of 16 flightless Canada Geese was seen just down stream from Manitou Falls. Three small groups were seen on August 17 and 18.

MALLARD - On August 22, a small flock flew overhead.

RED-BREASTED MERGANSER - We came to call them "pilot birds" because, on small lakes, August 11 to 17 , a family group often would swim parallel to our canoe, always keeping slightly ahead but off to one side, as if determined to beat us to the outlet. Even though we had detailed maps, hidden lake outlets always were a challenge to find. Two indicators that helped us to locate outlets accurately were our "pilot birds" and, in shallower sections, the subtle deflection of water "weeds" toward the outlet.

NORTHERN GOSHAWK - On August 22, about midday, a single Goshawk was seen.

ROUGH-LEGGED HAWK - On August 16 , a single one was seen overhead. 


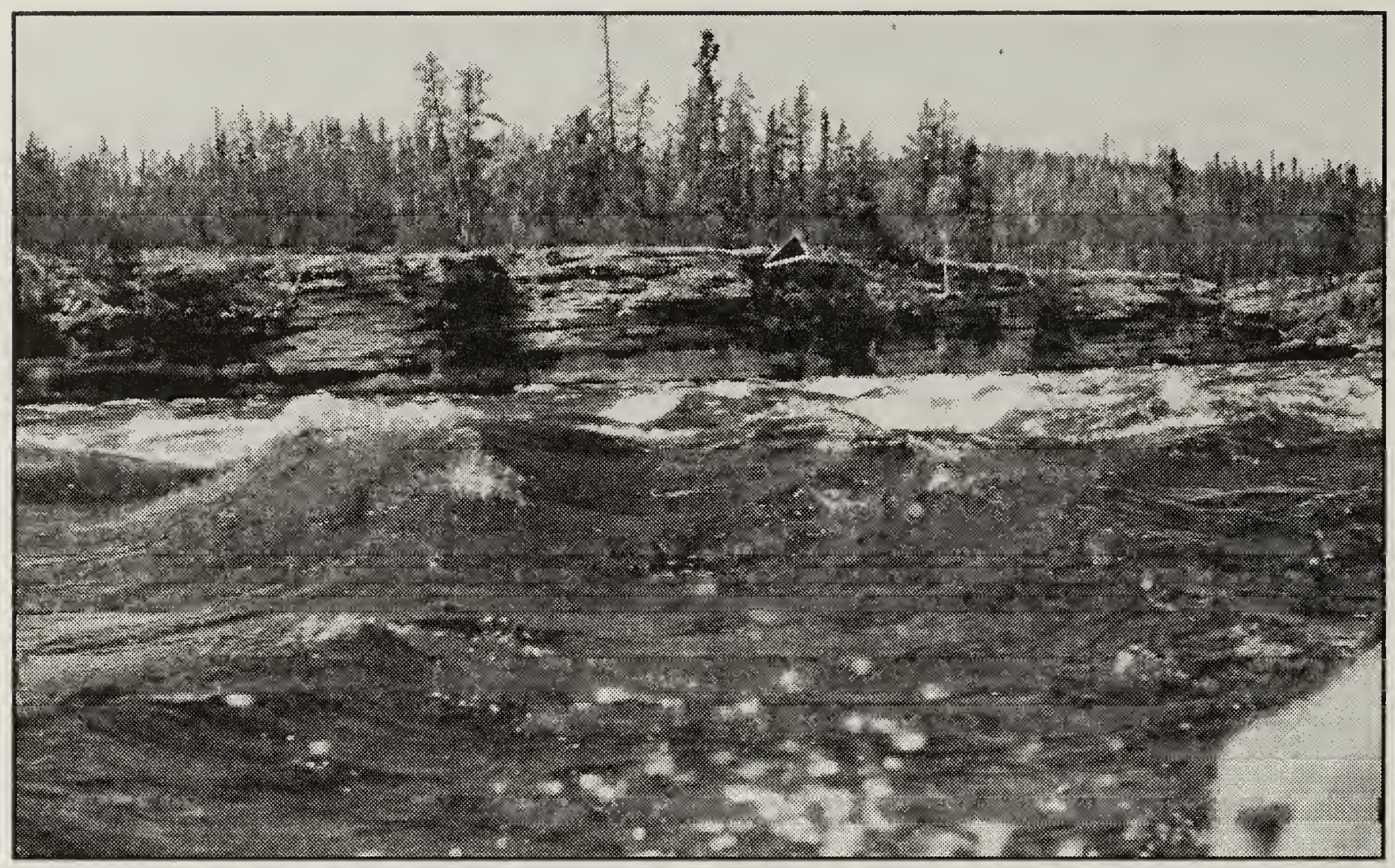

Fig. 1. Golden Eagle nest (arrow), Fond du Lac River

F. J.H. Fredeen

GOLDEN EAGLE - On August 16, we were surprised to find a small family of Golden Eagles near their nest on a cliff on the north side of the Fond du Lac River, between Manitou Falls and Brink Rapids (Fig. 1). This nest apparently was near or at the same location as that reported by Tyrrell in $1896 .{ }^{1}$

BALD EAGLE - On August 12 to 16, we observed Bald Eagles near their nests every 7 to $8 \mathrm{~km}$ along the Fond du Lac River between Kosdaw and Black lakes. On August 21, 5 more families near their nests were observed along the north side of the east arm of Lake Athabasca.

OSPREY - On August 18, we observed one fishing along the south shore of Black Lake.

SEMIPALMATED PLOVER - On August 19, four flew onto the beach near our camp on Black Lake. On August 24, three more were seen near our campsite on the MacFarlane River.
GREATER YELLOWLEGS - On August 22 and 23 , several pairs and small flocks were observed along the southeast shore of Lake Athabasca from Poplar Point south into the estuary of the MacFarlane River.

PARASITIC JAEGER - On August 22, two were seen flying along the north shore of the east arm of Lake Athabasca.

HERRING GULL - On August 22, several were seen along the east arm of Lake Athabasca.

TERN (presumed Arctic Tern) - Seen August 11 at the northwest end of Wollaston Lake, and on August 23, along the southwest shore of Lake Athabasca.

GREAT HORNED OWL - On August 22, one was seen about 20 miles west of the village of Fond du Lac.

BOREAL OWL - In the MacFarlane River valley, during the evenings just 
after sundown, on August 22 and 23, a Boreal Owl watched us from its perch on the top of a three-metre spruce tree a short distance from our tent. After calling for about 30 minutes, it would fly directly over us, apparently curious about our attempts to mimic it.

COMMON NIGHTHAWK - Between August 16 and 22, one or two were seen or heard every evening, flying overhead.

BELTED KINGFISHER - On August 17, single individuals were seen in two locations between Hawk Rock and Perch Rapids. On August 22, another was seen about $16 \mathrm{~km}$ west of Fond du Lac village.

NORTHERN FLICKER - On August 22, one was seen near the MacFarlane River and another in the sand dune area $1 \mathrm{~km}$ or so west of our camp site.

PILEATED WOODPECKER - On August 22, one was observed near the MacFarlane River.
CLIFF SWALLOW - On August 15, a large mixed flock of Barn and Cliff swallows was observed flying in and out of a red sandstone canyon below Red Bank Falls, so were presumed to be nesting together (Fig. 2).

BARN SWALLOW - (see Cliff Swallow, above).

COMMON RAVEN - Single ravens were seen on August 17 (between Hawk Rock and Perch Rapids) and on August 24 (Poplar Point on the east shore of Lake Athabasca). On August 23, a pair was seen near the MacFarlane River.

BOREAL CHICKADEE - On August 17, two were seen below Perch Rapids.

RUSTY BLACKBIRD - On August 17, a single blackbird was seen between Hawk Rock and Perch Rapids.

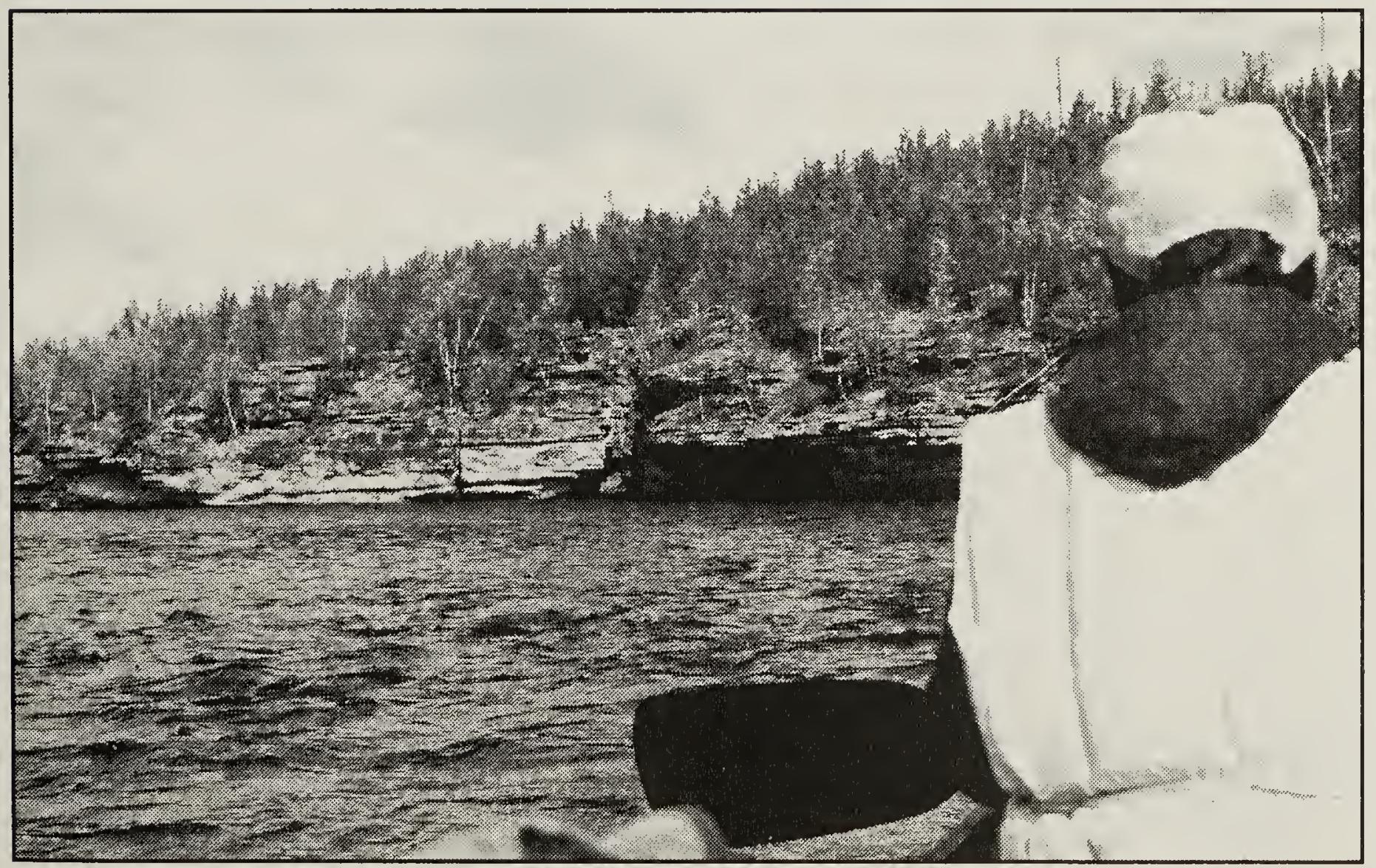


Acknowledgements:

I am much indebted to Howard and Greg (my companions on numerous wilderness trips over a period of 28 years) for their skilful piloting in rapids and in the difficult crossing of Lake Athabasca on August 24, but especially for their collaboration in identifying the 26 species of birds recorded herein.
1. Nero, R.W. 1963. Birds of the Lake Athabasca Region, Saskatchewan. Special Publication No. 5, Saskatchewan Natural History Society, Regina.

2. Renaud, W.E. 1998. Bird observations from northern Saskatchewan, August 1973. Blue Jay 56: 210-206.

Table 1. Locations of Overnight Campsites, August 1986.

\begin{tabular}{lllllll} 
Camp & Date & Location & \multicolumn{2}{c}{ Latitude (N) } & \multicolumn{2}{l}{ Longitude (W) } \\
& (August, 1986) & & Deg. & Min. & Deg. & Min. \\
1 & $10-11$ & S end of Wollaston Lake & 58 & 05 & 103 & 47 \\
2 & $11-12$ & Head of Fond du Lac River & 58 & 28 & 103 & 03 \\
3 & $12-13$ & Below Cascade Rapids & 58 & 43 & 103 & 54 \\
4 & $13-14$ & Waterfound River & 58 & 48 & 104 & 02 \\
5 & $14-15$ & SW end of Kosdaw Lake & 58 & 56 & 104 & 04 \\
6 & $15-16$ & Manitou Falls & 59 & 01 & 104 & 27 \\
7 & $16-17$ & Above Hawk Rock Rapids 59 & 01 & 105 & 03 \\
8 & $17-18$ & Below Perch Rapids & 59 & 10 & 104 & 46 \\
$9-10$ & $18-20$ & S shore of Black Lake & 59 & 09 & 105 & 14 \\
11 & $20-21$ & 2 km W of Stony Rapids & 59 & 16 & 105 & 53 \\
12 & $21-22$ & Fond du Lac Village & 59 & 19 & 107 & 11 \\
$13-14$ & $22-24$ & MacFarlane River & 59 & 11 & 107 & 57 \\
15 & $24-25$ & S of Poplar Point & 59 & 18 & 107 & 49 \\
16 & $25-26$ & N shore L. Athabasca & 59 & 23 & 107 & 50 \\
17 & $26-27$ & Crackingstone Point & 59 & 24 & 108 & 57 \\
$18-19$ & $27-29$ & NE end of Black Bay & 59 & 29 & 108 & 46 \\
\hline
\end{tabular}

"Of an estimated 75,000 edible plants found in nature, only 2,500 have ever been eaten with regularity, a mere 150 enter world commerce and a scant 20 , mostly domesticated cereals, stand between human society and starvation." 